Regan looked upon this genus as a survival from the base of the flatfish stem, to Chabanaud it was the latest departure from the path of percoid symmetry, and the more specialized soles and flounders were the modern twigs of earlier asymmetrical branches of the pre-percoid trunk. The fossils so far do not help to resolve this difference, for as Chabanaud himself was to describe, the main groups were already differentiated in the Upper Eocene.

The majority of Chabanaud's numerous publications after 1936 were on details of the morphology and classification of these asymmetrical fishes, in which he found an endless fascination. He applied to them a terminology of his own, which, in spite of its logical classicism, is unlikely to supersede current usage, which has 'just growed'. It was his ambition to write the second volume of the monograph of the flatfishes begun by J. R. Norman, but he began too late in life to analyse the many samples of soles and tongue-soles available to him and never arrived at a satisfactory synthesis.

Up to the eve of his last illness, Chabanaud would leave his flat in the Rue des Écoles at 8 a.m. and walk, painfully of late, to the laboratory in the Rue Cuvier to count more fin-rays and scales and cover more sheets with his endless tables. How I wish that in some Elysium it might be given him to draw from them the crystal truths that he was sure they would eventually yield! He could be a charming host, and one of his most engaging accomplishments was the relating of reminiscences, plunging into parenthesis after parenthesis without faltering in the elegant use of his mother-tongue and never failing to emerge triumphantly in the end as from a series of Chinese puzzle-boxes.

$\mathrm{He}$ was quite unworldly, a man of child-like integrity and innocence of mind. $\mathrm{He}$ is survived by his second wife, with whom he spent many years of mutual devotion.

E. Trewavas

\section{Prof. J. T. MacGregor-Morris}

Prof. J. T. MacGregor-Morris died on March 18, at the age of eighty-seven. He established the Electrical Engineering Department at East London College (now Queen Mary College) in 1898, and he became the first professor of electrical engineering in this College, a position which he held until he retired in 1938.

He received his education in electrical engineering at University College, London, and, for a time, was personal assistant to $\mathrm{Sir}$ Ambrose Fleming. He was keenly interested in research and during the Second World War he did notable work in developing a hydrophone for submarine detection.

An important contribution to electrical engineering education by Prof. MacGregor-Morris was the manner in which during the lean years immediately following the First World War he kept research work alive in his department, despite meagre equipment and small research funds. He kept the department open on three evenings a week, and he inspired and directed the research work of students who attended on these evenings. The students were of good calibre and they did good work. Several of them have risen to important positions in the electrical industry.

Under the leadership of its professor, the Department grew steadily in prestige, and its housing and equipment improved as the years passed. A notable development was the opening of its well-known High Voltage Laboratory in 1938 with the aid of a grant from the London County Council. This Laboratory was an example of Prof. MacGregor-Morris's foresight -.-he was a good judge of new developments which were likely to become of major importance in electrical engineering. Another example of this was his interest in the cathode-ray tube from its earliest days. He was joint author of one of the earliest text-books dealing with these tubes.

His lectures were interesting, stimulating and unorthodox with his over-riding interest in research always intruding.

His students and particularly his research students were important personages to him. Many of them will recall with pleasure the annual 'get-together' of staff and research students at his home in Hamp. stead. Mrs. MacGregor-Morris always took an active part on these occasions.

He was a very active man. On most Wednesday afternoons during term time he would play a strenuous game of tennis or badminton. He was keenly interested in music and, when quite elderly, he learned to play the 'cello and became a proficient performer on this instrument. He was a devout Christian and took an active interest in missionary work.

W. J. JOHN

\section{Dr. John Henderson, C.B.E.}

Dr. John Henderson, for seventeen years director of the New Zealand Geological Survey (N.Z. Department of Scientific and Industrial Research), died suddenly at his home on March 6. Born in Dunedin in 1880 , his later education was carried out at Otago Boys' High School, then at the University of Otago and Otago School of Mines. Here he completed, in 1902, his M.A. associateship of the School and B.E. (Mining).

For the next eight years he was director of Reefton School of Mines, during which time he devoted much energy to the investigation of the geological structure of the coal and gold mines of Westland and West Nelson, his thesis on the subject gaining him his D.Sc. in 1907.

In 1911 he was appointed mining geologist to the New Zealand Geological Survey. As well as keeping in touch with mining activities in the succeeding years, and reporting on numerous mines, quarries, and mineral properties of different kinds, he also reported on the geological implications of many engineering projects, for example the Arapuni Hydro-electric Dam on the Waikato River. In addition, he carried out extensive regional surveys of the geology and mineral resources of several districts. His bulletins on Reefton, Te Aroha (with J. A. Bartrum), Gisborne and Whatatutu (with M. Ongley), Mokau (with M. Ongley) and Huntly-Kawhia (with L. I. Grange) stand as lasting contributions to the geology of the Dominion.

At the request of the Fiji Government in 1923, Dr. Henderson visited and reported on the goology and mining prospects of gold-bearing quartz lodes in Vanua Levu.

Dr. Henderson, in 1928, succeeded the late P. G. Morgan as director of New Zealand Geological Survey and almost immediately encountered all the administrative difficulties and frustrations resulting from the financial stringency of the great economic depression. Nevertheless, by unremitting work he was able to keep his staff of geologists intact, and so actively to maintain the geological effort of New Zealand. Bulletins could no longer be printed, but 